\title{
Conceptualisation of Psychological Contract: Definitions, Typologies and Measurement
}

\author{
Larysa Botha (Corresponding author) \\ Graduate School of Business Leadership of University of South Africa (UNISA) \\ PO Box 392, UNISA, 003, South Africa
}

Tel: 27-824-981-245Ｅ-mail: larysa@vodamail.co.za

\section{Renier Steyn}

Graduate School of Business Leadership of University of South Africa (UNISA)

PO Box 392, UNISA, 003, South Africa

Tel: 27-116-520-254Ｅ-mail: steynr@unisa.ac.za

Received: June 8, $2021 \quad$ Accepted: July 18, $2021 \quad$ Published: July 22, 2021

doi: 10.5296/jsss.v8i2.18703 URL: https://doi.org/10.5296/jsss.v8i2.18703

\begin{abstract}
Background: Psychological contracts, and particularly the honouring of these contracts - are central to employee behaviour and organisational success. The interest of academics and practitioners in this construct is therefore understandable. However, due to the immense amount of information on the topic, a comprehensive review of the literature is necessary. Aim: The aim of this article is to present a critical review on the conceptualisation of the psychological contract, distilling and operationalising the concept, to ensure that debate and future research are linked to a dominant body of knowledge. Setting: Present literature on psychological contracts is fragmented as no conceptual standardisation exists. Method: A comprehensive literature review was conducted to obtain a large quantum of conceptualisations of the construct and evaluate these for breadth of adoption, consensus, and operationalisation. Results: After reviewing reputable sources published between 1960 and 2020, a standard definition proposed, the most recognised typologies specified, and sound measures identified. It was found that Rousseau's (1995) definition and typologies (transactional and relational contracts) are still widely used, and that the measuring scale for transactional and relational contracts by Millward and Hopkins (1998) demonstrates good
\end{abstract}


psychometric properties and broadly utilised. Conclusion: Since its inception, several amended definitions, typologies, and measurement of the psychological contract have been presented. Nonetheless, the original conceptualisations still seem to prevail. Managerial implications: Researchers and practitioners are now aware of the most widely adopted definitions, typologies and measuring instruments relating to psychological contract and these should guide them in future discussions and research in the field.

Keywords: Psychological contract, Psychological contract breach, Conceptualisation, Definition, Typology, Psychometric assessment

\section{Introduction}

Gaining the voluntary cooperation of workers has been a challenge faced by many organisations for more than a century. This is mostly due to the absence of effective control systems which would oblige a worker to willfully contribute to the organisation (Rousseau, 2011). It is commonly accepted that successful organisations depend on workers who volunteer their support. In the absence of effective formal control systems, vast body of existing and currently ongoing research on psychological contracts (PC) attempts to address the "fundamental, chronic, and, at times, acute dilemma" of voluntary cooperation (Rousseau, 2011, p. 191).

Cullinane and Dundon (2006) argue that significant interest from academics and practitioners in the PC concept is urged by a continuous need on the part of organisations to sustain employee motivation and commitment. Effective PCs are linked to positive employee attitudes and employment relationships, as well as to engaged and committed workers (Kutaula, Gillani, \& Budhwar, 2020; Schalk \& De Ruiter, 2019; Soares \& Mosquera, 2019; Tekleab, Laulié, De Vos, De Jong, \& Coyle-Shapiro, 2020), all of which are foremost resources that become critical for organisational survival and success (Agarwal \& Bhargava, 2013).

Despite the fact that the concept of the PC was born outside the human resources management (HRM) area, it has become a "major analytical device" in promoting HRM best practice (Cullinane \& Dundon, 2006, p. 113). This analytical device is empirically viable only if the conceptualisation and measurement of the PC are somewhat standardised. However, the measurement - and, by implication, conceptualisation - of the PC are disparate, as asserted by Rousseau and Tijoriwala (1998, p. 680), who state that "in the past 10 years, field research into [the] content and dynamics of psychological contracts in organizations has generated numerous published studies - with almost an equal number of somewhat distinct assessments". Although this assertion relates to the early stages of PC research, nowadays, "the lack of guidance for managers and organizations as to how they should practically use the psychological contract to manage the employment relationship" still remains a challenge (Conway \& Pekcan, 2019, p. 11). Such claims call for conceptual clarity and standardised assessment. This article will address the problem of the disparities highlighted above regarding the conceptualisation and measurement of the PC by presenting, integrating, and synthesising the literature on the topic. The evolution of the PC concept will be discussed next, with reference to the way in which the concept is defined, organised into typologies, and measured. Important in this regard is to address the matter of psychological contract 
breaches (PCB), as this is a variable often measured when PCs are researched (Paillé, Raineri, \& Valeau, 2016; Payne, Culbertson, Lopez, Boswell, \& Barger, 2015; Robinson \& Morrison, 2000; Robinson \& Rousseau, 1994; Rousseau, 2011; Thompson \& Bunderson, 2003; Tziner, Felea, \& Vasiliu, 2017). Thus, PCB will be also discussed.

\section{Defining Psychological Contracts}

The history of defining the PC concept can be divided into two periods (Banu, 2017; Conway \& Briner, 2009): the years before Denise Rousseau published her work "Psychological and implicit contracts in organizations" (1989), and the years after. Since the initial and her other seminal publications (ref. Rousseau, 1989, 1990, 1998, 2001), the definition of the PC as a concept has not evolved significantly and, as it will be demonstrated below, it can be concluded that subsequent and present-day theorists and researchers have adopted Rousseau's (1989) orthodox conceptualisation without significant modernisation or modification.

Even though Rousseau's comprehensive contribution is widely acknowledged as the standard, contemporary researchers still recognise others' inputs towards the development of the PC theory. Notable are the names of Argyris (1960), Levinson, Price, Munden and Solley (1962) and Schein (1965). Their definitions of the PC build on each other, are related in many ways, and will be presented first. These will be followed by definitions created by researchers, post-1998, who clearly adopted the contribution of the 'Rousseau school' (Guest, 1998, p. 673 ) in defining the PC.

- Argyris was the first to propose the term "psychological work contract" - this in his seminal work, "Understanding organizational behaviour", published in 1960. Although Argyris does not provide a clear definition, his description of features of the PC prompted later research towards the necessity of an exchange of some kind, and the existence of the implicit belief (Conway \& Briner, 2009). Argyris (1960) stated that the term "psychological work contract" describes the nature of the relationship between the [employees] and the [managers] as changing and developing, and which is highly dependent on the [managers'] leadership behaviour: "Since the [managers] realize the employees in this system will tend to produce optimally under passive leadership, and since the employees agree, a relationship may be hypothesized to evolve between the employees and the [managers] which might be called the 'psychological work contract'. The employee will maintain high production, low grievances, etc., if the [managers] guarantee and respect the norms of the employee informal culture (i.e., let the employees alone, make certain they make adequate wages, and have secure jobs). This is precisely what the employees need" (Argyris, 1960, p. 97).

- Levinson et al. (1962) first used the original term "psychological contract" in their book "Men, Management and Mental Health". They defined the psychological contract as "a series of mutual expectations of which the parties to the relationship may not themselves be even dimly aware but which nonetheless govern their relationship to each other" (Levinson et al., 1962 , p. 22). The authors continue to describe elements of the contract and state: "The psychological or unwritten contract is a product of mutual expectations. These have two characteristics: (a) they are largely implicit and unspoken, and (b) they frequently antedate the relationship of person and company" (Levinson et al., 1962, pp. 21-22). This contention makes a valuable contribution to understanding of the PC. The underlying assumption here is 
that on the unconscious level psychological needs of both, employees and employers, play an important role in defining the psychological contract. Furthermore, the fulfilment or failure to reciprocate affects mental health and well-being, where specifically unfulfilled psychological needs lead to frustration, anger and hostility (Conway \& Briner, 2009). Thus, defining reciprocity in terms of satisfaction of mutual needs between two parties to the agreement, and linking it to the PC concept is an important perspective, which influenced subsequent approaches in the development of the PC (Schalk \& De Ruiter, 2019).

- Schein (1965, p. 11) explains the PC from a perspective of the individual having "a variety of expectations ... not written into any formal agreement between employee and organisation, yet they operate powerfully as determinants of behaviour". Schein gives credit to both Levinson et al. (1962) and Argyris (1960) for their acknowledgement of the role of mutual expectations that individuals and organisations have of each other. He argues, that "these expectations not only cover how much work is to be performed for how much pay, but also involve the whole pattern of rights, privileges, and obligations between worker and organization" (Schein, 1965, p. 11). Schein sees the psychological contract as a path to a better understanding of the employment relationship. Schein's contribution in identifying the PC as central to organisational behaviour remains of value:

"It is my central hypothesis that whether a person is working effectively, whether he generates commitment, loyalty, and enthusiasm for the organization and its goals, and whether he obtains satisfaction from his work, depend to a large measure on two conditions: 1. The degree to which his own expectations of what the organization will provide him and what he owes the organization matches what the organization's expectations are of what it will give and get. 2. Assuming there is agreement on expectations, what actually is to be exchanged - money in exchange for time at work; social need satisfaction and security in exchange for work and loyalty; opportunities for self-actualization and challenging work in exchange for high productivity, quality work and creative efforts in the service of organizational goals; or various combinations of these and other things" (Schein, 1965, pp. 64-65).

These two eminent assumptions of Schein's - the first being the balance between employee's expectations and what he gets in return from his organisation, and second being the continuation of an exchange, either economic or social, or both - paved the way for how the $\mathrm{PC}$ concept developed in the years to follow.

The next milestone in the development of the PC is attributed to the work of Denise Rousseau. Conway and Briner (2009, p. 77) reference Rousseau's work as "the greatest influence on psychological contract research". Originally, in her first seminal paper, titled "Psychological and implied contracts in organizations", Rousseau (1989, p. 123) defined the PC as "individual's beliefs regarding the terms and conditions of a reciprocal exchange agreement between the focal person and another party. Key issues here include the belief that a promise has been made and a consideration offered in exchange for it, binding the parties to some set of reciprocal obligations".

Post 1989, both independently and jointly with her colleagues, Rousseau produced and inspired a number of papers providing more refined definitions of the concept. Listed below are definitions attributed to the Rousseau school (Guest, 1998, p. 673): 
1994: Psychological contracts can be "construed as a boundless bundle of obligations subjectively held... and ... comprised of a belief that some form of a promise has been made and that the terms and conditions of the contract have been accepted by both parties" (Robinson \& Rousseau, 1994, p. 246).

1994: "Psychological contracts refer to beliefs that individuals hold regarding promises made, accepted, and relied upon between themselves and another" (Rousseau \& Wade-Benzoni, 1994, p. 466).

1995: "The psychological contract is individual beliefs, shaped by the organization, regarding terms of an exchange agreement between individuals and their organization" (Rousseau, 1995, p. 9).

1996: The psychological contract comprises employees' "beliefs about what they are entitled to receive, or should receive, because they perceive that their employer conveyed promises to provide those things" in exchange for their contributions (Robinson, 1996, p. 575).

1997: "A psychological contract is commonly defined as an employee's beliefs about the reciprocal obligations between that employee and his or her organization, where these obligations are based on perceived promises and are not necessarily recognized by agents of the organization" (Morrison \& Robinson, 1997, p. 229).

1998: A psychological contract is "an individual's belief in mutual obligations between that person and another party such as an employer (either a firm or another person)" (Rousseau \& Tijoriwala, 1998, p. 679).

Common to the above definitions is that employees hold the belief that, in exchange for consideration promised by their organisation, they are bound to a set of reciprocal obligations, and vice versa.

In the following years and to date, while grounded in the Rousseau school conceptualisation, the lens through which the PC is explained and theorised has mainly remained unchanged.

The exploration of recent works on the PC shows that Rousseau's conceptualisation is still well accepted and adopted (see Boey \& Vantilborgh, 2016; Festing \& Schäfer, 2014; Griep \& Vantilborgh, 2018; McDermott, Conway, Rousseau, \& Flood, 2013). McDermott et al. (2013, p. 290) - and the presence of Rousseau in this group is specifically noted - provide a more recent definition that resembles Schein's notion of owing in its explanation of the concept, saying that: "psychological contracts refer to what employees believe they owe their employer as well as what they believe they are owed in return". Another definition, close to Rousseau's original, is the version by Daoud Abu-Doleh and Daddi Hammou: "A psychological contract is an implicit contract between an individual and his organization that specifies what each expects to give and receive from each other in their relationship" (2015, p. 36). Griep and Vantilborgh (2018, p. 141) extend Rousseau's (1995) definition of the PC "as a continuous exchange of a set of reciprocal obligations, arising from explicit and implicit promises, between the employee and the employer", adding "... which shapes the current and future employee-employer exchange relationship".

Despite advances in PC development in recent years, the lack of clarity in terms of how the concept is defined remains a cause for concern (Hansen, 2018). In their attempt at providing a sound foundation for clarity, Rousseau, Hansen and Tomprou (2018) define the PC as a 
"cognitive schema, or system of beliefs, representing an individual's perceptions of his or her own and another's obligations, defined as duties or responsibilities one feels bound to perform" (2018, p. 72).

From the aforementioned, it is difficult to stay away from the work of Rousseau when defining the PC, and the development of the PC concept seems not to have evolved much beyond her seminal work. As such, defining PC as "individual beliefs, shaped by the organization, regarding terms of an exchange agreement between individuals and their organization" (Rousseau, 1995, p. 9), would satisfy most scholars.

\section{Psychological Contract Breach}

Psychological contracts assume that employees expect their organisations to meet a large number of obligations as part of the explicit and implicit conditions within the employee-employer relationship (Deery, Iverson, \& Walsh, 2006; Morrison \& Robinson, 1997; Rousseau, 1989). When employees perceive that the organisation or its agent has failed to uphold its obligations, psychological contract breaches (PCB) occur (Morrison \& Robinson, 1997). These breaches are common in the workplace and became a norm, rather than an exception (Robinson \& Rousseau, 1994).

While the PC literature often uses the terms 'psychological contract breach' and 'psychological contract violation' interchangeably, Morrison and Robinson (1997) clearly distinguish between the two constructs. These authors argue that 'breach' represents a cognitive evaluation that one's organisation has failed to fulfil its obligations, whereas 'violation' is the emotional and affective state that may follow from the individual's perception of breach. In their meta-analysis, Zhao, Wayne, Glibkowski and Bravo (2007) further report that PC breach and violation display characteristics which suggest that they are distinct and, as such, it would be important to pay specific attention to which construct is studied and measured. The focus of this paper is explicitly on breach, not violation.

A large number of empirical research papers are dedicated to the PCB and its adverse effects on organisational outcomes. A wide array of negative consequences of PCB are found to impact employee attitudes and behaviours, such as a decline in job satisfaction, decreased organisational commitment, diminished organisational citizenship behaviour, increased absenteeism and turnover intention (Hartmann \& Rutherford, 2015; Kakarika, González-Gómez, \& Dimitriades, 2017; Kraak, Lunardo, Herrbach, \& Durrieu, 2017; Lu, Shen, \& Zhao, 2015; Suazo, 2009; Vander Elst, De Cuyper, Baillien, Niesen, \& De Witte, 2016).

Various types of psychological contract will be discussed next.

\section{Psychological Contract Typologies}

Although there are a multitude of forms of the psychological contract that have been featured in the theoretical and empirical research over the past three decades, there are four types that are commonly accepted by academia. These refer to transactional, relational, hybrid (balanced) and transitional psychological contracts. Of these four, the transactional and relational types of the PC are the most important forms of the employment relationship (Alcover, Rico, Turnley, \& Bolino, 2017). Being at the forefront of the research on PC, it is 
not surprising that the Rousseau school played a major role in differentiating between various PC types. Presented below is the development of the PC mainstream typology, followed by some (albeit minor) developments of alternative forms.

\subsection{The Rousseau School Typology}

Rousseau and McLean Parks (1993) and Rousseau and Wade-Benzoni (1994) distinguish between two major types of psychological contracts, which, they argue, have become common in the workplace. These two types of psychological contracts (transactional and relational) connect the ends of the contractual continuum (Macneil, 1985) where, on the one hand, transactional contracts focus on short-term and monetizable (economic) exchanges and can be characterised as "a fair day's work for a fair day's pay" (Rousseau \& Wade-Benzoni, 1994, p. 466). Examples of such contracts are commission-based sales, temporary employment and independent contracting (Rousseau \& McLean Parks, 1993). On the other side of the continuum are relational contracts, which involve open-ended relationships characterised by considerable investments from both parties. For example, employees will undergo costly, time-consuming, company-specific skills training and in return will remain with the company pursuing internal career opportunities. Rousseau and McLean Parks (1993) argue that such investments involve a high degree of mutual interdependence, making employment separation difficult. Further, they emphasise the dual nature of relational contracts. Unlike transactional contracts, which have a narrow monetary focus and are characterised by high levels of specificity (Rousseau \& McLean Parks, 1993), relational contracts combine both elements of exchange, that is the socio-emotional (loyalty and commitment) and the monetizable (consideration for services), and are flexible in nature (Rousseau \& McLean Parks, 1993).

Exploring the differences between the two types of the PC even further, Robinson and Rousseau (1994) suggest that, when bounded by the transactional contract, the employee values the instant rewards of the relationship, such as pay, training, and credentials, in order to obtain better future employment. In contrast, employees who are party to the relational contract believe in the long-term relationship with their employer and value the relationship itself, beyond the short-term gains from their employment (Robinson \& Rousseau, 1994).

Examined next is a two-item typology expanded into a four-item matrix, as theorised in the seminal paper of Rousseau (1995) titled "Psychological contracts in organizations: Understanding written and unwritten agreements". The author describes relationships between employees and employers in terms of time frames and performance requirements. 'Time frame' refers to the duration aspect of the employment relationship (i.e., short term vs. long term), while 'performance requirements' refer to the link between performance demands and employment rewards. According to Rousseau (1995), performance condition is a differentiator between relationships and transactions. The better defined the performance criteria, the more transactional a contract is. Rousseau (1995) suggests that, when considered in terms of these two dimensions, four forms of the psychological contract exist; transactional, relational, hybrid (balanced) and transitional psychological contracts, as illustrated in Table 1. 
Table 1. Types of psychological contracts

\begin{tabular}{|c|c|c|c|}
\hline & & PERFO & JCE TERMS \\
\hline & & Specified & Not Specified \\
\hline 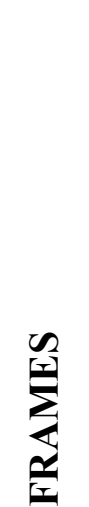 & 党 & $\begin{array}{l}\text { Transactional } \\
\text { Low ambiguity } \\
\text { Easy exit/high turnover } \\
\text { Low member commitment } \\
\text { Freedom to enter new contracts } \\
\text { Little learning } \\
\text { Weak integration/identification }\end{array}$ & $\begin{array}{l}\text { Transitional } \\
\text { Ambiguity/uncertainty } \\
\text { High turnover/termination } \\
\text { Instability }\end{array}$ \\
\hline$\sum_{i}$ & 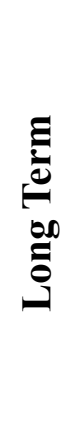 & $\begin{array}{l}\text { Hybrid/Balanced } \\
\text { High member commitment } \\
\text { High integration/identification } \\
\text { Ongoing development } \\
\text { Mutual support } \\
\text { Dynamic }\end{array}$ & $\begin{array}{l}\text { Relational } \\
\text { High member commitment } \\
\text { High affective commitment } \\
\text { High integration/identification } \\
\text { Stability }\end{array}$ \\
\hline
\end{tabular}

(Source: Rousseau, 1995, p. 98)

Although Rousseau's "traditional" transactional and relational two-item typology (Boey \& Vantilborgh, 2016; Vantilborgh et al., 2014) attracted the most attention from theorists and empirical researchers, the other two contract forms, hybrid (balanced) and transitional, beg a brief discussion.

The hybrid, or balanced, psychological contract is typical in knowledge organisations operating in highly competitive environments (Rousseau, 1995). This contract combines features of both forms of PC, transactional as well as relational (Dabos \& Rousseau, 2004). Hybrid (balanced) psychological contracts lead to employment relationships where the employer commits to developing workers and, in return, anticipates employees' willingness to adjust to changes (Rousseau, 2004).

Unlike the balanced PC, a hybrid of relational and transactional features, transitional psychological contracts reflect a "breakdown of the employment relationship or the absence of a solid agreement between the parties" (Hui, Lee, \& Rousseau, 2004, p. 312). Hui et al. (2004) argue that transitional arrangements are not uncommon during times of economic downturn, downsizing and radical changes when trust and commitment between contracting parties have eroded or ceased to exist (2004, p. 312). In more recent studies, it has been found that transitional contracts are associated with negative work outcomes, including low work engagement (Soares \& Mosquera, 2019), diminished well-being and negative work attitudes 
(Zolnierczyk-Zreda, 2016).

\subsection{Other Typologies of the Psychological Contracts}

Rousseau's work inspired further research on the PC typology and new forms of contracts appeared post-Rousseau's conceptualisations. Apart from being new, their acceptance and popularity in the general PC literature are not as broad as Rousseau's, but some brief discussion is warranted.

Ideology-infused psychological contracts are typical as part of employment relationships where the employee perceives that organisation is "obligated to demonstrate a credible commitment to and investment in a valued cause or principle" (Thompson \& Bunderson, 2003, p. 574). In return, the employee is obligated to reciprocate in a way such that his or her actions will promote the organization's ability to pursue the cause. Bingham (2005) empirically found that ideology-infused contracts positively affect participation, advocacy, support of national performance, and promotion of organisational objectives and policies. Haibin (2008) suggests that ideological alignment is an independent dimension of the psychological contract. When individuals have a high level of ideological alignment with their organisations, they succeed in regulating their relations with the employer (Wang \& Yu, 2011). Although it is assumed that an ideology is based on an individual's system of having particular ideological commitments (Rajabipoor Meybodi, Mortazavi, KafashPoor, \& Lagzian, 2016), the roots of these sentiments have not been widely explored, either theoretically or empirically (Wang \& Yu, 2011). Understandably, Rajabipoor, Meybodi et al. (2016) advocate for the necessity of developing ideological dimensions of the psychological contracts within the psychological framework.

Psychological contracts based on balanced and unbalanced social exchange are grounded in Blau's (1964) social exchange theory (Shore \& Barksdale, 1998). Shore and Barksdale (1998) developed a psychological contract typology where employment relations can be evaluated based on two underlying dimensions, which include a) the degree of balance, and b) a level of obligation shared between the employer and employees. Following these dimensions, the authors proposed four types of psychological contract: mutual high obligations, mutual low obligations, employee under-obligation and employee over-obligation, as shown in Table 2 below. 
Table 2. Exchange Relationships

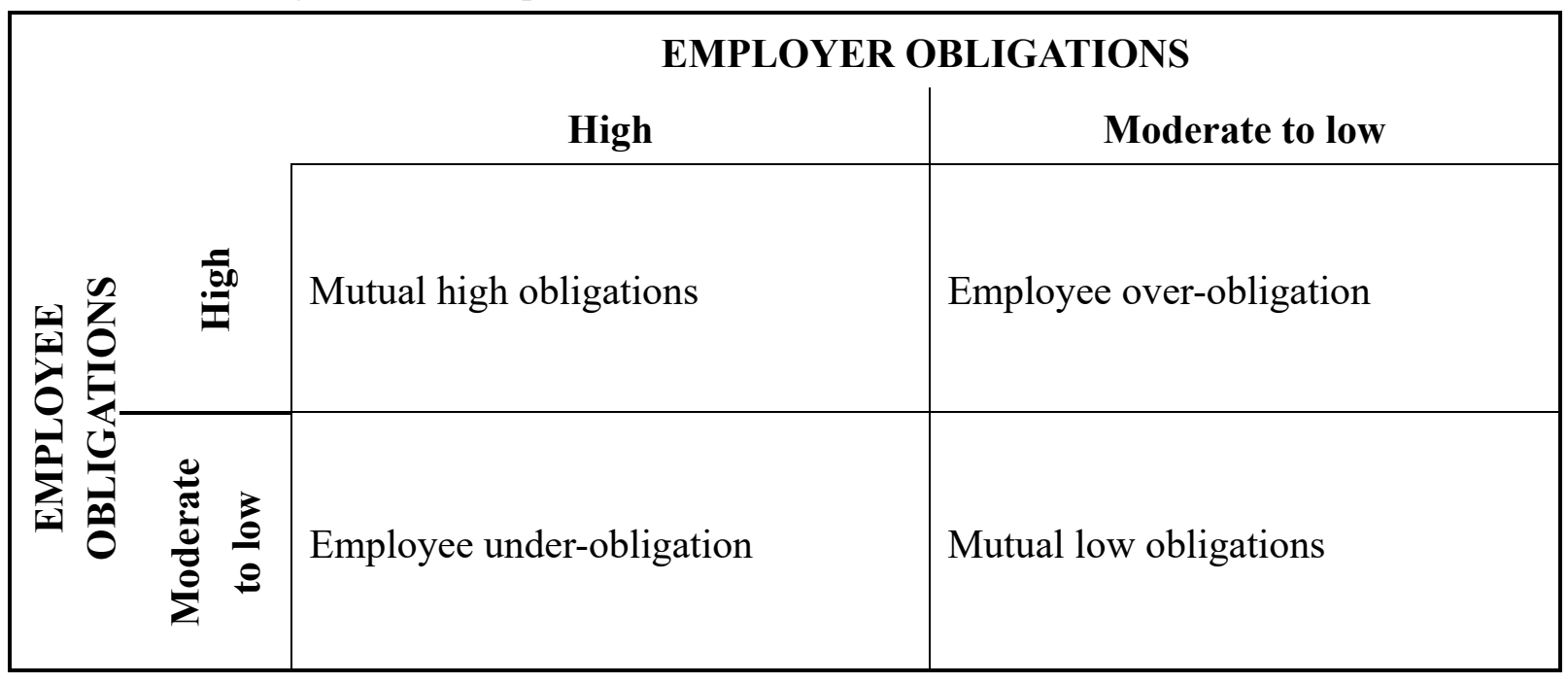

(Source: Shore and Barksdale, 1998, p. 734)

In cases of mutual high obligations and mutual low obligations, these psychological contracts are considered balanced. In both, the employee and the employer are equally obligated in the exchange, despite the two types of contracts resulting in opposite outcomes. While mutual low obligation contracts yield undesirable employee outcomes, mutual high obligation contracts result in positive, desirable outcomes for the organisation, where employees demonstrate higher levels of affective involvement, intentions to stay, rather than leave, and perceived high organisational support (Shore \& Barksdale, 1998).

The other two types of contracts, referred to as unbalanced, are employee over-obligation and employee under-obligation psychological contracts and are characterised by the lack of balance in employee's obligations. Between the two, the employee under-obligation PC manifests in the poorest outcomes amongst all four types. According to Shore and Barksdale (1998), the unbalanced contracts are less prevalent and rather of a temporary nature, which is in line with Blau's (1964) posits that parties to the social exchanges typically pursue the balance and that they feel that they are obliged to give something in return for what they received.

Although the development of the PC concept has evolved into a broad range of types, the transactional-relational distinction remains the most frequently used typology in the PC literature (Boey \& Vantilborgh, 2016).

\section{Measurement of the Psychological Contract and Breach}

The review of the extant literature revealed a multitude of ways in which the PC and the PCB are measured. The disparities between existing measurement instruments are broad. Conway and Briner (2005, p. 94) point out that it is of no surprise that "there are a variety of measures for assessing both breach and the contents of psychological contracts, showing there is no single, agreed-upon measure of either of these constructs". Freese and Schalk (2008) evaluated a wide range of questionnaires for measuring the PC. Based on their analysis of the "enormous variation" of the PC measuring instruments, the authors affirm that most 
questionnaires do not meet the conceptual validity criteria $(2008$, p. 281). In line with the seminal work of Rousseau (1989), these authors recommend that, when selecting a scale, Rousseau (1990) should be used for a short list of items, and Freese and Schalk (2008) for an extended list of items. Rousseau's (2000) instrument is also recommended as it provides scales with multiple usage opportunities.

Another group of measuring instruments is also recommended by Freese and Schalk (2008). Those instruments address specific aspects of the PC and, for this reason, can be useful, depending which on specific constructs are studied and measured. This group includes the instruments of Robinson and Morrison (2000), measuring contract breach and violation, and the instrument of Millward and Hopkins (1998), assessing specific contract orientation (relational and transactional).

Rousseau's (2000) Psychological Contract Inventory (PCI) is considered etic (Note 1) and is widely used in empirical studies (Bankins, 2015; Cassar, Briner, \& Buttigieg, 2016; Hui et al., 2004; Raja, Johns, \& Ntalianis, 2004; Scheepers \& Shuping, 2011; Vantilborgh et al., 2014). It is designed to measure the quality of employment relationships utilising a conceptual framework grounded in organisational theory and research (Rousseau, 1995; Rousseau \& Wade-Benzoni, 1994). The PCI assesses relational, transactional, balanced, and transitional psychological contract types. The instrument measures levels of belief in terms of employee and organisational obligations, as well as contract transitions and fulfilment.

The PCI is comprised of four sections, with 72 items in total. Each item is measured on a five-point Likert scale ranging from 1 - "Not at all" to 5 - "To a great extent". Respondents are asked to answer questions related to each section. Sample items in each section follow below:

Employee Obligations (28 items in total):

"To what extent have you made the following commitments or obligations to your employer?"

(1) ... I have no future obligations to this employer

(2) ... I only perform specific duties I agreed to when hired.

Employer Obligations (28 items in total):

"Consider your relationship with your current employer. To what extent has your employer made the following commitments or obligations to you?"

(1) ... My employer makes no commitments to retain me in the future

(2) ... My employer is concerned for my long-term well-being.

Psychological Contract Transitions (12 items in total):

"To what extent do the items below describe your employer's relationship to you?"

(1) ... My employer doesn't share important information with its workers

(2) ... My employer demands more from me while giving me less in return.

Psychological Contract Fulfilment (4 items in total):

(1) Overall, how well have you fulfilled your commitment to your employer?

(2) In general, how well does your employer live up to its promises? 
Rousseau (2000) reports average reliability, with a Cronbach's alpha of .77 across all four sections. One year prior to its public release, and in collaboration with Rousseau, Ang and Goh (1999); tested the PCI was in Singapore by using the subset of items taken from the Rousseau's instrument. For this study, the three items (of the original five) per subset with the highest item-total correlations were selected and tested. The authors reported an average Cronbach's alpha of .81 across four sections with the reduced number of items (Ang \& Goh, 1999). In her publication, Rousseau (2000) included reliability results for both the full and reduced versions of the PCI.

Millward and Hopkins' (1998) Psychological Contract Scale (PCS) is recommended by Freese and Schalk (2008) for measuring specific contract orientations, relational and transactional. This 33-item instrument assesses the strength of relational and transactional psychological contracts. Each is measured on a seven-point Likert scale ranging from 1 "Strongly disagree" to 7 - "Strongly agree". The PCS incorporates 20 items related to the transactional sub-scale and 13 items related to the relational sub-scale.

Transactional sample items:

(1) ... I do this job just for the money

(2) ... I only carry out what is necessary to get the job done.

Relational sample items:

(1) ... To me working for this organization is like being a member of a family

(2) ... My job means more to me than just a means of paying the bills.

Millward and Hopkins (1998, p. 1541) report that all of the relational items are internally consistent, obtaining a Cronbach's alpha of .86. All transactional items were also reliably interrelated, obtaining a Cronbach's alpha of .88. The authors also add that, in both instances, all item-total correlations were above .30. Furthermore, it was found that subscale scores were negatively correlated $(\mathrm{r}=-0.61, \mathrm{p}<.01)$, meaning that the higher the relational orientation, the lower the transactional orientation, and vice versa (Millward \& Hopkins, 1998, p. 1542).

When selecting the instrument for measuring the PCB, Freese and Schalk (2008) recommend the measure by Robinson and Morrison (2000) as a good instrument that meets the conceptual validity criteria. Furthermore, Rousseau (2011, p. 211) indicates that the measurement instrument for breach and violation by Robinson and Morrison (2000) is developed in a "theoretically consistent fashion". The following discussion describes the instrument in more detail.

Robinson and Morrison (2000) developed a nine-item measurement scale, of which four items measure violation and the other five measure breach.

The self-reported violation, measured on a 5-point Likert scale, ranging from 1 - "Strongly disagree" to 5 - "Strongly agree", indicates the extent to which respondents evaluate how they feel about the employer's violation of the contract. Sample items include:

(1) ... I feel a great deal of anger toward my organization

(2) ... I feel betrayed by my organization.

The self-reported breach is measured by the reverse scoring of a fulfilment measure on a scale of 1 to 5 (disagree-agree). Sample items include: 
(1) ... Almost all the promises made by my employer during recruitment have been kept so far (reversed)

(2) ... I feel that my employer has come through in fulfilling the promises made to me when I was hired (reversed).

Robinson and Morrison (2000) reported that the violation measure was significantly correlated with the measure of perceived contract breach at $\mathrm{r}=0.68$ and $\mathrm{p}<0.01$. Furthermore, considering the magnitude of this correlation, the authors conducted a factor analysis to test whether these two constructs are empirically distinct. The results provide clear evidence of discriminant validity. All the perceived breach items loaded onto the first factor, with loadings ranging from .70 to .87. All the violation items loaded separately onto the second factor, with loadings ranging from .79 to .89 (Robinson \& Morrison, 2000, p. 538).

It is interesting to note the creative approach taken in contemporary research of using fulfilment and breach scales simultaneously, combining composite and global measures. According to Zhao et al. (2007), a composite measure refers to various content items of the psychological contract - for example, training, job security and pay. The researcher will typically ask respondents to what extent the organisation has fulfilled its obligation on each item.

In the composite measure, meanwhile, each content item is considered individually, and the global measure evaluates the respondent's overall perception of how much the organisation has fulfilled or failed to fulfil its promises. A typical example of the global measure is the sample item from Robinson and Morrison's (2000) psychological contract breach scale stating: "Almost all the promises made by my employer during recruitment have been kept thus far" (reverse scored) (Zhao et al., 2007). An example of combining composite and global measures is the study by Tekleab, Laulié, De Vos, De Yong and Coyle-Shapiro (2020), where authors in one section used the composite scale by De Vos, Buyens and Schalk (2003) for psychological contract fulfilment, and in a different section, a global scale by Robinson and Morrison (2000) for breach.

Another interesting example of assessing the PC - and, particularly, a multi-party PC - is the Repertory Grid Technique (RGT). Sherman and Morley (2020) utilise RGT to better understand multi-party psychological contracts, that is where one party (in this case, an employee of the courier company concerned) evaluates the multiple expectations an individual holds towards the other three parties in the "tetradic employment relationship" (Sherman \& Morley, 2020, p. 27). The authors confirm that various contributing parties in the employment relationship each hold different beliefs of what the other parties are obliged to provide and what is expected in return, which is aligned with sentiments proposed by Schalk and Rousseau (2001).

As the result of summarising and evaluating available instruments for the PC and PCB, it is suggested that the measurements that seem most appropriate are the PCS by Millward and Hopkins (1998) for measuring transactional and relational contracts, and the instrument of Robinson and Morrison (2000) for measuring breach and violation. Both scales demonstrated sound conceptual foundations and good psychometric properties, lending credence to their selection in the future investigations. 


\section{Summary}

This article contributes to the PC literature in three ways. Firstly, it offers a contemporary synthesis of the conceptualisation of the $\mathrm{PC}$, considering the many ways in which it has been defined previously. Given this analysis and synthesis, it was concluded that the PC could best be defined as "individual beliefs, shaped by the organization, regarding terms of an exchange agreement between individuals and their organization" (Rousseau, 1995, p. 9).

Secondly, it provides an updated and comprehensive summary of the types of PC. Typologies are central to the conceptualisation of the PC, as they flow naturally from concepts (Mouton, 1996). The most widely used typologies were found to be the transactional and relational types of the PC, making up, as they do, the most important forms of the employment relationship (Alcover et al., 2017).

The last contribution lies within summarising the available measures of the PC as well as $\mathrm{PCB}$, reflecting on how the measures depict the conceptual structures which underpinned their development. The measurement of the PC which seemed most appropriate was the Psychological Contract Scale (PCS) by Millward and Hopkins (1998) and the instrument of Robinson and Morrison (2000) for measuring PCB. While both scales demonstrated strong conceptual foundations and good psychometric properties, the PCS is preferred as it assesses both, relational and transactional contracts.

\section{Conclusion}

This paper aimed at providing a comprehensive review of reputable sources published between the years 1960 and 2020. Since the emergence of the psychological contract as a concept, several amended definitions, typologies, and measurement have been presented, but the original conceptualisations still seem to prevail. Researchers and practitioners are now aware of the most widely respected and adopted definitions, typologies and measuring instruments relating to psychological contract, which should guide them in their discussion of the topic as well as research in this field.

\section{References}

Agarwal, U. A., \& Bhargava, S. (2013). Effects of psychological contract breach on organizational outcomes: Moderating role of tenure and educational levels. Vikalpa, 38(1), 13-25. https://doi.org/10.1177/0256090920130102

Alcover, C. M., Rico, R., Turnley, W. H., \& Bolino, M. C. (2017). Understanding the changing nature of psychological contracts in 21 st century organizations: A multiple-foci exchange relationships approach and proposed framework. Organizational Psychology Review, 7(1), 4-35. https://doi.org/10.1177/2041386616628333

Ang, G., \& Goh, K. (1999). Motivational traits and psychological contracts in Singapore. Nanyang Technological University, Singapore.

Argyris, C. (1960). Understanding organizational behavior. Homewood, IL: Dorsey Press.

Bankins, S. (2015). A process perspective on psychological contract change: Making sense of, and repairing, psychological contract breach and violation through employee coping actions. Journal of Organizational Behavior, 36(8), 1071-1095. https://doi.org/10.1002/job.2007 
Banu, S. P. (2017). A literature review on the psychological contract - the pre-rousseau account and post-rousseau account of psychological contract. Asian Journal of Multidimensional Research, 6(12), 66-72.

Bingham, J. (2005). Multiple obligations: Distinguishing the dimensionality and confirming the role of ideology within the psychological contract framework. Annals of Physics, (August), 258.

Blau, P. (1964). Power and exchange in social life. New York, NY: John Wiley \& Sons.

Boey, L., \& Vantilborgh, T. (2016). A theoretical model relating the dark triad of personality to the content of employees' psychological contracts. New Zealand Journal of Employment Relations, 40(3), 44-66.

Cassar, V., Briner, R. B., \& Buttigieg, S. (2016). What's in a broken promissory obligation? Developing and testing a multiple component form measure of psychological contract breach. International Journal of Human Resource Management, 27(5), 567-592. https://doi.org/10.1080/09585192.2015.1025089

Conway, N., \& Briner, R. B. (2005). Understanding psychological contracts at work. A critical evaluation of theory and research. Oxford: Oxford University Press. https://doi.org/10.1093/acprof:oso/9780199280643.001.0001

Conway, N., \& Briner, R. B. (2009). Fifty years of psychological contract research: What do we know and what are the main challenges. International Review of Industrial and Organizational Psychology, 21(1), 71-131. https://doi.org/10.1002/9780470745267.ch3

Conway, N., \& Pekcan, C. (2019). Psychological contract research: Older, but is it wiser? In Y. Griep \& C. Cooper (Eds.), Handbook of Research on the Psychological Contract at Work (pp. 10-34). Chaltenham, UK: Edward Elgar. https://doi.org/10.4337/9781788115681.00009

Cullinane, N., \& Dundon, T. (2006). The psychological contract: A critical review. International Journal of Management Reviews, 8, 113-129. https://doi.org/10.1111/j.1468-2370.2006.00123.x

Dabos, G. E., \& Rousseau, D. M. (2004). Mutuality and reciprocity in the psychological contracts of employees and employers. Journal of Applied Psychology, 89(1), 52-72. https://doi.org/10.1037/0021-9010.89.1.52

Daoud Abu-Doleh, J., \& Daddi Hammou, M. (2015). The impact of psychological contract breach on organizational outcomes: The moderating role of personal beliefs. Journal of Competitiveness Studies, 23(1\&2), 34-55.

De Vos, A., Buyens, D., \& Schalk, R. (2003). Psychological contract development during organizational socialization: Adaptation to reality and the role of reciprocity. Journal of Organizational Behavior, 24(5), 537-559. https://doi.org/10.1002/job.205

Deery, S. J., Iverson, R. D., \& Walsh, J. T. (2006). Toward a better understanding of psychological contract breach: A study of customer service employees. Journal of Applied Psychology, 91(1), 166. https://doi.org/10.1037/0021-9010.91.1.166

Festing, M., \& Schäfer, L. (2014). Generational challenges to talent management: A framework for talent retention based on the psychological contract perspective. Journal of World Business, 49(2), 262-271. https://doi.org/10.1016/j.jwb.2013.11.010 
Freese, C., Schalk, R., \& Croon, M. (2008). The Tilburg Psychological Contract Questionnaire | De Tilburgse Psychologisch Contract Vragenlijst. Gedrag En Organisatie, 21(3), 278-294.

Freese, Charissa, \& Schalk, R. (2008). How to measure the psychological contract? A critical criteria-based review of measures. South African Journal of Psychology, 38(2), 269-286. https://doi.org/10.1177/008124630803800202

Griep, Y., \& Vantilborgh, T. (2018). Reciprocal effects of psychological contract breach on counterproductive and organizational citizenship behaviors: The role of time. Journal of Vocational Behavior, 104, 141-153. https://doi.org/10.1016/j.jvb.2017.10.013

Guest, D. E. (1998). On meaning, metaphor and the psychological contract: A response to Rousseau. Journal of Organizational Behavior, 19, 673-677. https://doi.org/10.1002/ (SICI)1099-1379(1998)19:1+<673::AID-JOB973>3.0.CO;2-Z

Haibin, F. (2008). The empirical study on the ideological contrast of the staff. He Nan University.

Hartmann, N. N., \& Rutherford, B. N. (2015). Psychological contract breach's antecedents and outcomes in salespeople: The roles of psychological climate, job attitudes, and turnover intention. Industrial Marketing Management, 51, 158-170. https://doi.org/10.1016/j. indmarman.2015.07.017

Hui, C., Lee, C., \& Rousseau, D. M. (2004). Psychological contract and organizational citizenship behavior in China: Investigating generalizability and instrumentality. Journal of Applied Psychology, 89(2), 311-321. https://doi.org/10.1037/0021-9010.89.2.311

Kakarika, M., González-Gómez, H. V., \& Dimitriades, Z. (2017). That wasn’t our deal: A psychological contract perspective on employee responses to bullying. Journal of Vocational Behavior, 100, 43-55. https://doi.org/10.1016/j.jvb.2017.02.005

Kraak, J. M., Lunardo, R., Herrbach, O., \& Durrieu, F. (2017). Promises to employees matter, self-identity too: Effects of psychological contract breach and older worker identity on violation and turnover intentions. Journal of Business Research, 70, 108-117. https://doi.org/10.1016/j.jbusres.2016.06.015

Kutaula, S., Gillani, A., \& Budhwar, P. S. (2020). An analysis of employment relationships in Asia using psychological contract theory: A review and research agenda. Human Resource Management Review, 30(4), 100707. https://doi.org/10.1016/j.hrmr.2019.100707

Levinson, H., Price, C. R., Munden, K. J., \& Solley, C. M. (1962). Men, management, and mental health. Cambridge, MA: Harvard University Press. https://doi.org/10.4159/harvard. 9780674424746

Lu, Y., Shen, Y., \& Zhao, L. (2015). Linking psychological contract breach and employee outcomes in China: Does leader-member exchange make a difference? Chinese Economy, 48(4), 297-308. https://doi.org/10.1080/10971475.2015.1044856

Macneil, I. R. (1985). Relational contract: What we do and do not know. Wisconsin Law Review, (3), 483-525. https://doi.org/10.3366/ajicl.2011.0005

McDermott, A. M., Conway, E., Rousseau, D. M., \& Flood, P. C. (2013). Promoting effective psychological contracts through leadership: The missing link between HR strategy and 
performance. Human Resource Management, 52(2), 289-310. https://doi.org/10.1002/ hrm. 21529

Millward, L. J., \& Hopkins, L. J. (1998). Psychological contracts, organizational and job commitment. Journal of Applied Social Psychology, 28(16), 1530-1556.

Morrison, E. W., \& Robinson, S. L. (1997). When employees feel betrayed: A model of how psychological contract violation develops. Academy of Management Journal, 22(1), 226-256. https://doi.org/10.5465/AMR.1997.9707180265

Mouton, J. (1996). Understanding social research. Pretoria: Van Schaik.

Paillé, P., Raineri, N., \& Valeau, P. (2016). The effects of the psychological contract among professional employees working in non-professional organizations. Relations Industrielles / Industrial Relations, 71(3), 521-543. https://doi.org/https://dx.doi.org/10.7202/1037663ar

Payne, S. C., Culbertson, S. S., Lopez, Y. P., Boswell, W. R., \& Barger, E. J. (2015). Contract breach as a trigger for adjustment to the psychological contract during the first year of employment. Journal of Occupational and Organizational Psychology, 88(1), 41-60. https://doi.org/10.1111/joop.12077

Raja, U., Johns, G., \& Ntalianis, F. (2004). The impact of personality on psychological contracts. Academy of Management Journal, 47(3), 350-367. https://doi.org/10.5465/ 20159586

Rajabipoor Meybodi, A., Mortazavi, S., KafashPoor, A., \& Lagzian, M. (2016). Developing a framework for studying and evaluating the types of psychological contracts in the context of relationship marketing. Iranian Journal of Management Studies, 9(1), 2008-7055.

Robinson, S. L., \& Morrison, E. W. (2000). The development of psychological contract breach and violation: A longitudinal study. Journal of Organizational Behavior, 21(5), 525-546. https://doi.org/10.1002/1099-1379(200008)21:5<525::AID-JOB40>3.0.CO;2-T

Robinson, S. L., \& Rousseau, D. M. (1994). Violating the psychological contract: Not the exception but the norm. Journal of Organizational Behavior, 15, 245-259. https://doi.org/10.1002/job.4030150306

Rousseau, D. M. (1989). Psychological and implied contracts in organizations. Employee Responsibilities and Rights Journal, 2(2), 121-139. https://doi.org/10.1007/BF01384942

Rousseau, D. M. (1990). New hire perceptions of their own and their employer's obligations: A study of psychological contracts. Journal of Organizational Behavior, 11(5), 389-400. https://doi.org/10.1002/job.4030110506

Rousseau, D. M. (1995). Contract Making. In Psychological contracts in organizations: Understanding written and unwritten agreements (pp. 23-54). https://doi.org/10.4135/ 9781452231594

Rousseau, D. M. (1998). Why workers still identify with organizations. Journal of Organizational Behavior, 19(3), 217-233. https://doi.org/10.1002/(SICI)1099-1379 (199805)19:3<217::AID-JOB931>3.0.CO;2-N

Rousseau, D. M. (2000). Psychological Contract Inventory. In Tech. Rep. No. 200--2002. Pittsburgh, PA: The Heinz School of Public Policy and Management, Carnegie Mellon University. 
Rousseau, D. M. (2001). Schema, promise and mutuality: The building blocks of the psychological contract. Journal of Occupational \& Organizational Psychology, 74(4), 511-541. https://doi.org/10.1348/096317901167505

Rousseau, D. M. (2004). Psychological contracts in the workplace: Understanding the ties that motivate. The Academy of Management Executive, 18(1), 120-127. https://doi.org/10.5465/ame.2004.12689213

Rousseau, D. M. (2011). The individual-organization relationship: The psychological contract. In S. Zedeck (Ed.), APA Handbook of Industrial and Organizational Psychology, Vol.3: Maintaining, Expanding, and Contracting the Organization (pp. 191-220). https://doi.org/10.1037/12171-005

Rousseau, D. M., Hansen, S. D., \& Tomprou, M. (2018). A dynamic phase model of psychological contract processes. Journal of Organizational Behavior, 39(9), 1081-1098. https://doi.org/10.1002/job.2284

Rousseau, D. M., \& McLean Parks, J. (1993). The contracts of individuals and organizations. Research in Organizational Behavior, 15(1), 1-43.

Rousseau, D. M., \& Tijoriwala, S. A. (1998). Assessing psychological contracts: Issues, alternatives and measures. Journal of Organizational Behavior, 19(7), 679-695. https://doi.org/10.1002/(SICI)1099-1379(1998)19:1+<679::AID-JOB971>3.0.CO;2-N

Rousseau, D. M., \& Wade-Benzoni, K. A. (1994). Linking strategy and human resource practices: How employee and customer contracts are created. Human Resource Management, 33(3), 463-489. https://doi.org/10.1002/hrm.3930330312

Schalk, R., \& De Ruiter, M. (2019). Mutuality and reciprocity in the psychological contract: A critical review and analysis. In Y. Griep \& C. Cooper (Eds.), Handbook of Research on the Psychological Contract at Work (pp. 35-62). Edward Elgar. https://doi.org/10.4337/97817881 15681.00010

Schalk, R., \& Rousseau, D. M. (2001). Psychological contracts in employment. In N. Anderson, D. S. Ones, H. Kepir Sinangil, \& C. Viswesvaran (Eds.), Handbook of industrial, work \& organizational psychology (pp. 133-142). SAGE Publications, Thousand Oaks. https://doi.org/10.4135/9781848608368.n8

Scheepers, C. B., \& Shuping, J. G. (2011). The effect of human resource practices on psychological contracts at an iron ore mining company in South Africa. South African Journal of Human Resource Management, 19(1), 1-19. https://doi.org/10.4102/sajhrm. v9i1.302

Schein, E. H. (1965). Organizational psychology. Englewood Cliffs, NJ: Prentice-Hall.

Sherman, U. P., \& Morley, M. J. (2020). What do we measure and how do we elicit it? The case for the use of repertory grid technique in multi-party psychological contract research. European Journal of Work and Organizational Psychology, 29(2), 230-242. https://doi.org/10.1080/1359432X.2019.1668844

Shore, L. M., \& Barksdale, K. (1998). Examining degree of balance and level of obligation in the employment relationship: A social exchange approach. Journal of Organizational Behavior, 19(S1), 731-744. https://doi.org/10.1002/(SICI)1099-1379(1998)19:1+<731:: 
AID-JOB969>3.0.CO;2-P

Soares, M. E., \& Mosquera, P. (2019). Fostering work engagement: The role of the psychological contract. Journal of Business Research, 101(August), 469-476. https://doi.org/10.1016/j.jbusres.2019.01.003

Suazo, M. M. (2009). The mediating role of psychological contract violation on the relations between psychological contract breach and work-related attitudes and behaviors. Journal of Managerial Psychology, 24(2), 136-160. https://doi.org/10.1108/02683940910928856

Tekleab, A. G., Laulié, L., De Vos, A., De Jong, J. P., \& Coyle-Shapiro, J. A. M. (2020). Contextualizing psychological contracts research: A multi-sample study of shared individual psychological contract fulfilment. European Journal of Work and Organizational Psychology, 29(2), 279-293. https://doi.org/10.1080/1359432X.2019.1608294

Thompson, J. A., \& Bunderson, J. S. (2003). Violations of principle: Ideological currency in the psychological contract. Academy of Management Review, 28(4), 571-586. https://doi.org/10.5465/AMR.2003.10899381

Tziner, A., Felea, M., \& Vasiliu, C. (2017). Psychological contract breach, leader-member exchange, perceived ethical climate and organisational justice: Are they interrelated and how? Journal of East European Management Studies, 22(1), 63-82. https://doi.org/10.5771/ 1862-0019-2017-1-63

Vander Elst, T., De Cuyper, N., Baillien, E., Niesen, W., \& De Witte, H. (2016). Perceived control and psychological contract breach as explanations of the relationships between job insecurity, job strain and coping reactions: Towards a theoretical integration. Stress and Health, 32(2), 100-116. https://doi.org/10.1002/smi.2584

Vantilborgh, T., Bidee, J., Pepermans, R., Willems, J., Huybrechts, G., \& Jegers, M. (2014). Effects of ideological and relational psychological contract breach and fulfilment on volunteers' work effort. European Journal of Work and Organizational Psychology, 23(2), 217-230. https://doi.org/10.1080/1359432X.2012.740170

Wang, B., \& Yu, B. (2011). Content, fulfilment and prospects of ideology-infused psychological contract. 8th International Conference on Service Systems and Service Management - Proceedings of ICSSSM'11, 1-5. Tianjin, China: IEEE.

Zhao, H., Wayne, S. J., Glibkowski, B. C., \& Bravo, J. (2007). The impact of psychological contract breach on work-related outcomes: A meta-analysis. Personnel Psychology, 60, 647-680. https://doi.org/10.1111/j.1744-6570.2007.00085.x

Zolnierczyk-Zreda, D. (2016). Psychological contract in the light of flexible employment: The review of studies/Kontrakt psychologiczny w swietle elastycznego zatrudnienia pracownikow: Przeglad badan. Medycyna Pracy, 67(4), 529-536. https://doi.org/10.13075/mp. 5893.00328

\section{Notes}

Note 1. Reference to the etic nature of the instrument means that the instrument assesses general constructs, typically derived from theory and meaningful to participants across variety of settings (Rousseau \& Tijoriwala, 1998). In contrast, emic frameworks address 


\section{Macrothink}

Journal of Social Science Studies

ISSN 2329-9150

2021, Vol. 8, No. 2

factors arising out of an organisation's culture and setting-specific content as regards the psychological contract.

\section{Copyright Disclaimer}

Copyright for this article is retained by the author(s), with first publication rights granted to the journal.

This is an open-access article distributed under the terms and conditions of the Creative Commons Attribution license (http://creativecommons.org/licenses/by/4.0/). 